Zbornik Instituta za kriminološka

i sociološka istraživanja

2020 / Vol. XXXIX / 2-3 / 93-107

Pregledni naučni rad

Primljeno: 22. novembra 2020. godine

Prihvaćeno: 21. decembra 2020. godine

DOI: $10.47152 /$ ziksi2020236

UDK: 343.85

351.778 .5

502.131.1:711.432/.434

\title{
PREVENCIJA KRIMINALA KAO PRISTUP UNAPREĐENJU URBANE BEZBEDNOSTI*
}

\author{
Ana Paraušić*
}

\begin{abstract}
Kriminal u gradovima jedan je od najduže tematizovanih problema u kriminologiji, a savremeno proučavanje ovog fenomena povezuje se sa konceptom urbane bezbednosti. Iz ove perspektive urbani kriminal, pre svega, možemo posmatrati kao bezbednosnu pretnju, a prevenciju urbanog kriminala kao jedan od modela, politika ili bezbednosnih mera, koje provajderi bezbednosti sprovode kako bi ostvarili bezbednost u gradu. Predmet ovog rada stoga je prikaz glavnih odlika prevencije kriminala u gradovima koja je u funkciji unapređenja urbane bezbednosti. $U$ prvom delu rada napravljen je osvrt na neke teorïjske pretpostavke na kojima se zasniva savremeno proučavanje prevencije urbanog kriminala. Potom su prikazani pojedini modeli, strategije $i$ politike prevencije kriminala u gradovima, koji su zasnovani na bogatoj istraživačkoj praksi u ovoj oblasti. Na kraju, date su neke preporuke za adekvatno planiranje programa prevencije kriminala koje bi moglo doprineti sveukupnom podizanju nivou urbane bezbednosti.
\end{abstract}

KLJUČNE REČI: urbani kriminal / prevencija kriminala / urbana bezbednost

\footnotetext{
*Ovaj tekst je nastao kao rezultat na projektu "Kriminal u Srbiji: fenomenologija, rizici i mogućnost socijalne intervencije" (broj 47011) koji finansira Ministarstvo prosvete, nauke i tehnološkog razvoja Republike Srbije

* Istraživač saradnik u Institutu za kriminološka i sociološka istraživanja, Beograd. E-mail: parausicana@gmail.com
} 


\author{
Zbornik IKSI, 2-3/202O - A. Paraušić \\ „Prevencija kriminala kao pristup unapređenju urbane bezbednosti”, (str. 93-107)
}

\begin{abstract}
UVOD
Urbani kriminal, ili kriminal u gradovima tradicionalno je jedan od tematizovanih fenomena u kriminologiji. Međutim, poslednje dve decenije, sve češce se urbana bezbednost spominje kao okvir za proučavanje brojnih problema u gradovima, među kojima svakako dominantno mesto zauzima kriminal, njegova prevencija i društvena kontrola. Odraz velikog interesovanja kriminologa za ovu temu predstavlja i posebno izdanje „Evropskog časopisa za kriminologiju“ (European Journal of Criminology) iz 2013. godine, koje je u potpunosti posvećeno fenomenu bezbednosti u gradovima. U pomenutom broju razmatraju se teme vezane za konceptualizaciju i operacionalizaciju urbane bezbednosti u različitim sredinama, zatim kompartivne studije politika bezbednosti u evropskim gradovima, urbani bezbednosni menadžment, izazovi, pretnje i akteri urbane bezbednosti i sl. Očekivano, kriminolozi nastoje da pitanje bezbednosti u gradovima prevashodno povežu sa fenomenom urbanog kriminala, te se unapređnje bezbednosti u urbanim sredinama često izjednačava sa prevencijom kriminala i ostalih oblika antidruštvenog ponašanja.
\end{abstract}

O aktuelnosti pomenute teme svedoči i sve veći angažman regionalnih i međunarodnih organizacija na planu prevencije urbanog kriminala, koji se često „prelivao“ na nacionalne i urbane politike bezbednosti. Uviđajući razmere i posledice urbanog kriminala u gradovima širom sveta, Svetska zdravstvena organizacija je još 1989. godine pokrenula Program za bezbednost zajednice, sa posebnim naglaskom na prevenciju. Nešto kasnije, 1996. godine, urbano nasilje je uvršteno u goruće probleme, koji zahteva ozbiljne napore na planu prevencije, u smislu sprovođenja istraživanja i objavljivanja publikacija (Danilović-Hristić, 2014:3). Uvažavajući značaj gradova kao samostalnih ekonomskih, političkih i društvenih entiteta i smatrajući da odvijanje gradskog života i dinamike podleže nadnacionalnoj regulativi, evropska tela, saveti i organizacije su postavili pitanja od značaja za bezbednost gradova na agendu evropske politike (Paraušić, 2019a: 111). Evropski savet je davne 1992. godine usvojio „Evropsku urbanu povelju“ (European Urban Charter) prema kojoj je prevencija kriminala, zasnovana na sedam bazičnih principa, osnova za unapređenje bezbednosti u urbanim sredinama. ${ }^{1}$ Osim toga, osnivanjem Evropskog foruma za urbanu bezbednost (European Forum for Urban Security), uticajne nevladine organizacije koja je u značajnoj meri zaslužna za promovisanje koncepta urbane bezbednosti na evropskom tlu, iskazana je potreba sagledavanja uzroka kriminala i njegove prevencije $\mathrm{u}$ kontekstu socijalne pravde i ekonomskih politika u evropskim gradovima (Paraušić, 2019a: 107). Ovim, i sličnim inicijativama, nedvosmisleno je iskazana potreba da se bezbednost u gradu i prevencija urbanog kriminala sagledavaju kao međupovezani fenomeni.

\footnotetext{
${ }^{1}$ Ukazujući na potrebu prilagođavanja savremenim uslovima, Evropski savet je 2008. godine usvojio „Evropsku urbanu povelju II - Manifest nove urbanosti“ (European Urban Charter II - Manifesto for New Urbanity), gde je ponovljen imperativ prevencije kriminala kao uslov bezbednosti u gradu, uz neke osavremenje pristupe koji se tiče inkluzivnosti i održivosti.
} 


\section{Zbormik IKSI, 2-3/202O - A. Paraušić \\ „Prevencija kriminala kao pristup unapređenju urbane bezbednosti”, (str. 93-107)}

Često se u kriminološkim diskusijama i rasprava ističe kako bezbednost u gradu trebalo da obuhvata različite dimenzije, te pojedini autori napominju da je jedan od osnovnih aspekata urbane bezbednosti, pored brige za dobrobit svih građana i kvaliteta urbane infrastrukture, upravo prevencija kriminala i antidruštvenih ponašanja (Recasens et al., 2013), ili da su politike urbane bezbednosti, zapravo politike za prevenciju kriminala i nasilja (Tulumello, 2017). Međutim, uprkos ovim nastojanjima, i dalje se nije odmaklo previše u pogledu proširivanje istraživačkog polja urbane bezbednosti mimo tradicionalnog proučavanja različitih dimenzija kriminala u urbanim sredinama, te se $\mathrm{u}$ istraživanjima urbane bezbednosti, zapravo ispituje kako strah od kriminala u urbanim sredinama, tako i preventivne i reaktivne strategije za sprečavanje ovog problema na nivou grada (Paraušić, 2019b: 120).

Autori iz oblasti studija bezbednosti, stava su da urbanu bezbednost treba posmatrati značajno šire, kao bezbednost koja se ostvaruje na nivou grada, i koja obuhvata nekoliko dimenzija: štićene vrednosti, bezbednosne pretnje, provajdere (pružaoce) bezbednosti i bezbednosne mere (Paraušić, Lipovac, 2019). Kombinacija različitih faktora i problema sa kojima se savremeni gradovi suočavaju razlikuje ih od ruralnog, nacionalnog ili međunarodnog okruženja, te pružanje bezbednosti i reagovanje na bezbednosne pretnje zahteva posebno kreirane odgovore i koordinaciju i saradnju aktera koji deluju u urbanom prostoru. Iz ove perspektive urbani kriminal pre svega možemo posmatrati kao bezbednosnu pretnju, a prevenciju urbanog kriminala kao jedan od modela, politika ili bezbednosnih mera, koje provajderi bezbednosti sprovode kako bi ostvarili bezbednost $\mathrm{u}$ gradu kao vrednost koju treba zaštititi.

Predmet ovog rada stoga je prikaz glavnih odlika prevencije kriminala u gradovima koja je u funkciji unapređenja urbane bezbednosti. U prvom delu rada napravljen je osvrt na neke teorijske pretpostavke na kojima se zasniva savremeno proučavanje prevencije urbanog kriminala. Potom su prikazani pojedini modeli, strategije i politike prevencije kriminala u gradovima, koji su zasnovani na bogatoj istraživačkoj praksi u ovoj oblasti. Na kraju, date su neke preporuke za adekvatno planiranje programa prevencije kriminala koje bi moglo doprineti sveukupnom podizanju nivou urbane bezbednosti, kako objektivnih pokazatelja, tako i subjektivnog doživljaja ljudi koji svakodnevno koriste urbani prostor.

\section{TEORIJSKE PRETPOSTAVKE PREVENCIJE KRIMINALA U URBANIM SREDINAMA}

Etabliranan je naučni zaključak da postoji kompleksna i zavisna veza između kriminala, izazvanog straha i načina na koji se ljudi ponašaju u prostoru kao njegovi korisnici. Prema nalazima sprovedenih istraživanja može se zaključiti da se kod pojedinaca i grupa smanjuje potreba za mobilnošću, usled nespremnosti da se napusti prostor doživljen kao bezbedan (Lorenc et al., 2012: 760); smanjuju se šanse za bolje zaposlenje ili prilike za školovanje (Whitzman, 2008); slabe socijalni kontakti, smanjuje se poverenju u zajednicu i institucije (Đurić, 2013). Strah od viktimizacije uličnim kriminalom, doprinosi tome da građani 
izbegavaju prostore koje doživljavaju kao nebezbedne, što u krajnjem doprinosi smanjenju kvaliteta života u gradu, ali i deterioracije, odnosno gubljenja osnovne funkcije nekog prostora, što dovodi do njegove zapuštenosti. Stoga je pravilno planiranje i implemetntacija preventivnih programa usmerenih na redukciju urbanog kriminala, kako broja krivičnih dela, tako i straha građana, od velikog značaja za unapređenje urbane bezbednosti.

Bazični istraživački napori na području povezivanja planiranja i uređenja prostora sa kvalitetom života u zajednici možemo pripisati Džejn Džejkobs (Jane Jacobs) koja je u svojoj knjizi Smrt i život velikih američkih gradova pisala o otvorenim prostorima kao sastajalištima koja povezuju zajednicu i povećavaju „broj očiju na ulici“ (eays on the street), odnosno prirodni nadzor u zajednici. Nakon ove studije, razvijena su brojna kriminološka i sociološkda objašnjenja koja povezuju odlike prostora i prevalenciju krivičnih dela u urbanom okruženju. Među teorijskim pristupima koji su imali značajnog uticaja na pristupe prevencije urbanog kriminala spomenućemo teoriju društvene dezorganizacije, prema kojoj su stope kriminala u direktnoj veza sa prostornim karakteristikama u zajednici. Prema glavnim pretpostavkama ove teorije mesto gde pojedinac živi može biti prediktor kriminalnog ponašanja, u većoj meri nego što su to individualne karakteristike (Shaw, McKey, 1942). Drugi srodni pristupi, posebno teorija „slomljenih prozora“, naglašavaju da zapuštanje i zanemarivanje otvorenih gradskih provršina dovodi do njihove disfunkcionalnosti, te su mesta u kojima se češce vrše krivična dela (Wilson, Keling, 1982). Prema ovom teorijskom pristupu održavanje i nazor urbanog okruženja u cilju sprečavanja manjih prestupa, poput pijenja na javnim mestima ili vandalizma, omogućava stvaranje prostora u kojem vlada javni red, čime se sprečava nastanak težih krivičnih dela. ${ }^{2}$

Jedno od uticajnih objašnjenja prediktora straha od kriminala, koje ovaj problem povezuje sa karakteristikama životnog okruženja, jeste istraživački model nereda (Incivilities Thesis). Uobičajeno se misli na društveni nered koji se izražava kroz razne oblike nepristojnog ponašanja uz nepostojanje nadzora: aktivnosti bandi, beskućništvo ili život u zapuštenim objektima, alkoholizam, javno pijenje i narkomanija, prosjačenje, adolescenti bez nadzora, psi lutalice itd. (Đurić, 2013: 539). Osim društvenog, ovaj model podrazumeva i znake fizičkog propadanja, koji se zbirno pripisuju tzv. fizičkom neredu: ostavljeni automobili, demolirani objekti, napuštene zgrade, đubre itd. Model nereda zasniva se na pretpostavci da manifestacije nereda u lokalnom okruženju, kao znaci propadanja, lokalne stanovnike ugrožavaju više nego realan kriminal (Worrall, 2006; Lorenc et al., 2012: 761-62). Uočeni znaci društvenog i fizičkog nereda mogu biti pokazatelj odsustva društvene kontrole, pa se može očekivati da će građani koji žive u ovakvim kvartovima pokazivati i veći stepen straha od kriminala (Swat et al., 2013).

Na tragu pomenutih teorijskih pretpostavki razumljiva su nastojanja da se bogata istraživačka praksa u ovoj oblasti pretoči u praktična rešenja urbanog planiranja u

\footnotetext{
${ }^{2}$ Međutim, postoje i autori koji veruju da je nemoguće potvrditi uzročno posledičnu povezanost između društvenog i fizičkog nereda u susedstvu i kriminala (v. Sampson, Raudenbush, 2004)
} 


\section{Zbormik IKSI, 2-3/202O - A. Paraušić \\ „Prevencija kriminala kao pristup unapređenju urbane bezbednosti”, (str. 93-107)}

funkciji prevencije kriminala u gradovima. Na taj način se kreiraju efikasnije politike urbane bezbednosti, destimulativno deluje na prestupnike, a modifikovan izgled pojedinih urbanih lokacija doprinosi povećanju osećaja bezbednosti kod građana (Đurić, Paraušić, 2017). Dobro isplanirani projekti urbanog uređenja koji uvažavaju bezbednosnu dimenziju, mogu da doprinesu stvaranju pristupačnih i prijatnih javnih urbanih prostora, u kojima se građani osećaju sigurno, koji doprinose društvenoj koheziji, i smanjuju stres kod ljudi. Sigurni javni prostori predstavljaju neki vid „bafer zone“ (Chan, Lee, 2008: 253) gde se ljudi slobodno okupljaju i stupaju u razne vidove interakcija.

U nastavku ćemo stoga, predstaviti neke modele i programe prevencije urbanog kriminala, kao i eventualne preporuke i smernice za kreiranje adekvatnih i sveoubhvatnih preventivnih programa u funkciji redukcije urbanog kriminala.

\section{NEKI MODELI I PRIMERI PREVENCIJE KRIMINALA U URBANIM SREDINAMA}

Prevencija kriminala može se odvijati na brojnim nivoima; od međunarodnog, preko nacionalnog, pa do individualnih preventivnih ponašanja. Jedna od specifičnosti prevencije kriminala u urbanim sredinama tiče se naročito prostorne dimenzije, imajući u vidu da prostor i njegove odlike mogu uticati na to kako ljudi doživljavaju ili koriste taj prostor. Jedan od bazičnih pretpostavki je da uređeni i osvetljeni gradski prostori odvraćajuće deluje na potencijalne učinioce krivičnih dela, dok sa druge strane mračni i zapušteni prostori obično stvaraju kako strah kod ljudi koji koriste taj prostor, tako i priliku za učinioce zločina.

U ekstremnim situacijama, strah i nasilje mogu biti povezani sa određenim delovima grada u tolikoj meri da podstiču socioprostornu segregaciju i produbljivanje jaza među građanima različitih socio-ekonomskih mogućnosti. Susedstva ili kvartovi tako postaju stigmatizovane zone u koje se ne ide (no-go-zones), koje su davno napustili kako imućniji građani, tako i predstavnici formalne socijalne kontrole (Danilović-Hristić, 2014).

U literaturi i praksi prepoznati su brojni tipovi odgovora na kriminal u gradovima. Jedna od postojećih klasifikacija obuhvata šest široko postavljenih grupa pristupa (UN-Habitat, 2007: 96):

1. Unapređenje urbane bezbednosti putem planiranja, dizajna $i$ upravljanja. Pomoću ove tri grupe aktivnosti moguće je manipulisati i upravljati izgrađenim okruženjem, u okviru koga može doći do krivičnog dela.

2. Pristupi unapređenju urbane bezbednosti zasnovani u zajednici. Aktivnosti u okviru ovih pristupa podrazumevaju da zajednica preuzme inicijativu u prevenciji kriminala. Grupe ili pojedinci se u ovom slučaju javljalu ili kao inicijatori ideja ili kao ključni akteri u njihovoj impelemntaciji. 
3. Jačanje kapaciteta pravosuđa i policije. Iako se ovo posmatra kao „klasičan“ odgovor na kriminal, unapređenje kapaciteta policijskih snaga i pravosudnih organa je neophodno u prevenciji zločina.

4. Uticaj na rizične faktore. Uobičajeno su pristupi u okviru ove grupe usmereni ka grupama čiji su članovi u riziku da postanu učinioci ili žrtve zločina.

5. Nenasilno rešavanje sukoba. Uobičajeno se misli na pristupe upravljanja konfliktnim situacijama kako bi se smanjio rizik od nastanka nasilja, ili pronašli nenasilni ishodi.

6. Jačanje društvenog kapitala. U okviru ovuh pristupa fokus je na jačanju sposobnosti ljudi, grupa i zajednica da se suoče sa problemom kriminala.

Ovako široko postavljeni pristupi često će obuhvatiti strategije koje imaju elemente koji su međusobno povezani, te ni pomenute kategorije nisu isključujuće. Često će prevencija kriminala u pojedinim urbanim susedstvima, a koja je usmerena na mlade, podrazumevati određene izmene izgrađenog okruženja u kojem mladi mogu provoditi više slobodnog vremena.

Ideja o prevenciji kriminaliteta kroz uređenje okoline i urbani dizajn (Clarke, 1982), se razvijala tokom sedamdesetih godina prošlog veka kao odgovor na snažan porast kriminaliteta i straha od kriminala u gradovima Sjedinjeni Američkih Država (Balgač, 2013: 89). U okviru ovog opšteg okvira razvila su se tri pristupa i to: prevencija kriminala kroz uređenje okoline (Crime prevention through environmental design), odbranjivi prostor (defensible space) i situaciona prevencija kriminaliteta. Među pomenutim pristupima, CPTED i odbranjivi prostor polaze od teritorijalnosti kao ključnog načela u stvaranju bezbednih zajednica, te su u tom smislu specifičniji za urabni prostor, imajući u vdu da situaciona prevencija ima deleko opštiji karakter, u smisli da se može primeniti u bilo kom okruženju. CPTED kombinuje elemente psihologije i arhitekture fokusirajući se prvenstveno na dizajn stambenih blokova i karakteristike stambenih parcela sa namerom stvaranja „branjenih prostora“ i minimiziranja mogućnosti za kriminalno ponašanje i aktivnosti (Jeffery, 1971; Newman, 1972). Uglavnom se navodi da CPTED ima četiri karakteristike: teritorijalnost, nadzor, kontrolu pristupa i održavanje/spoljni izgled (City of Virgina Beach, 2000; National Crime Prevention Council, 2003). Prostorno planiranje i urbani dizajn sastavni su delovi mnogih inicijativa za prevenciju kriminaliteta u Kanadi33, Australiji i Novom Zelandu4, Holandiji5, Velikoj Britaniji (CSIR, 2001). Evaluacija programa prevencije sa implementiranom dimezijom CPTED u proteklih nekoliko decenija pokazuju da se ovaj pristup pozitivno odrazio na smanjenje stopa kriminaliteta u gradoviama (Cozens, Saville, Hiler, 2005).

\footnotetext{
3 U Kanadi je CEPTD implementiran kako kroz planiranje izgradnje u gradovima, stambenih zgrada, škola i za ostvarenje interakcije stanara i društvene kohezije (Weller, 2006).

4 Vlade ove dve zemlje razvile su zakonodavni okvir za implementaciju CPTED te su savezne države usvojile kodekse ili smernice zasnovane na CPTED (Crime prevention Ottawa, 2009).

5 Policija Holandije je priredila priručnik o bezbednom stanovanju i izgradnji stanova kroz dizajn, kako bi olakšali arhitektama i urbanistima planiranje kuća koje su neprivlačne potencijalnim provalnicima. Nakon pilot projekta, zabeležen je pad kriminaliteta od čak 70\% (Weller, 2006).
} 


\section{Zbornik IKSI, 2-3/202O - A. Paraušić \\ „Prevencija kriminala kao pristup unapređenju urbane bezbednosti”, (str. 93-107)}

Osnovne ideje CPTED-a insiprisale su inicijativu Sigurni putem dizajna (Secured by Design) koji preporučuje integraciju prevencije kriminala u programe planiranja (Armitage, 2004). Slične ideje bile su osnov za kreiranje prvog evropskog standarda za smanjenje kriminala kao i straha od kriminala putem urbanog planiranja. Zaštita od kriminala - Urbano planiranje i dizajn zgrada (Prevention of crime - Urban planning and building design - CEN 14383) pruža smernice za procenu rizika od kriminala i/ili straha od kriminala i mere i procedure za njihovo smanjivanje (COST, 2014).

Jedan od aktuelnih pristupa proteklih nekoliko decenija je i ozelenjavanje urbanog gradskog prostora kao strategija prevencije kriminala. Pojedina istraživanja pokazala su da prisustvo ili odsustvo vegetacije utiče na različite tipove kriminaliteta, te, na primer, imovinska krivična dela i uznemiravanje imaju veću stopu nego nasilnički kriminal za koji se beleže stope opadanja u vezi sa prisustvom zelenih površina (Bogar, Beyer, 2015 prema Pavićević, 2019). Pored toga, brojni američki gradovi pokrenuli su kampanje ozelenjivanja u cilju poboljšanja održivosti grada, ali i unapređenja bezbednosti zajednica. Iako autori ukazuju da ne možemo doći do definitivnih zaključaka o povezanosti urbane zelene infrastrukture i kriminala $\mathrm{u}$ gradovima, „veći broj studija je pokazao da dobro uređeno i dobro raspoređeno gradsko zelenilo ima potencijala u smanjivanju i odvraćanju od nasilja i kriminala“ (Pavićević, 2019: 60).

Osim pomenutih, postoje brojne strategije za smanjenje stopa kriminala i straha od kriminala u kojima se prepoznaje uticaj bogate istraživačke prakse, a koje podrazumevaju implementaciju tehničkih rešenja i upotrebu savremenih tehnologija. Takvi su projekti poboljšanja uličnog osvetljenja (Welsh, Farrington, 2008a) kao i sistem zatvorene televizije (Closed Circuite television -CCTV) (Welsh, Farrington, 2008b), komuniciranje u kriznim situacijama, prediktivni policijski rad pomoću informaciono-komunikacionih tehnologija, monitoring društvenih mreža itd. Međutim, treba imati u vidu da uvođenje različitih oblika nadzora uvodi brojne izazove. Može se opravdano postaviti pitanje vlasništva i upravljanja sistemima zatvorene televizije i pristupa podacima o građanima koje kamere beleže, odnosno njihove zloupotrebe. Usled ovoga, građani mogu percipirati pojačan nadzor više kao pretnju svojoj privatnosti, negoli efikasno sredstvo odrvaćanja potencijalnih učinilaca.

Ovde je korisno pomenuti i inicijative nastale u okviru koncepta „Pametnog grada“ (Smart city), čija je osnovna ideja transformacija upravljanja gradom, pružanja usluga i načina života pomoću modernih digitalnih tehnologija (Kitchin, Dodgge, 2017: 1). Tehnologije razvijane u okviru inicijative Pametnog grada promovisane su kao efikasan i efektivan način pružanja usluge bezbednosti (Paraušić, 2018), među kojima je prevencija uličnog kriminala jedan od vodećih pristupa. Raste broj online platformi i aplikacija koje građani mogu koristiti kako bi prijavili zločin, diskutovali o bezbednosnim problemima sa kojima se suočavaju, upozorili sugrađane o 
nebezbednim lokacijama. ${ }^{6}$ Osnovna prednost ovih digitalnih rešenja jeste što su široko dostupna građanima, sa informacijama koje se mogu pratiti u realnom vremenu, interaktivna i, uglavnom, jednostavna za korišćenje uz posedovanje smart uređaja. Nedostaci su svakako vezani za različiti stepen tehnološke pismenosti stanovništa, kao i socio-ekonomski status koji onemogućava svima da imaju adekvatan uređaj za instalaciju pomenutih aplikacija. Ovo je naročito važno ukoliko se uzme u obzir da su marginalizovani i najsiromašniji građani češce žrtve krivičnih dela.

Među pristupima prevencije urbanog kriminala mogu se izdvojiti i strategije koje se ne fokusiraju direktno na prevenciju zločina u gradovima, već, generalno, na unapređenje urbane bezbednosti. Među njima autori izdvajaju: pacifikaciju, projekat policije u zajednici7, programe fokusirane na rizične grupe, urbanu obnovu, reformu upravljanja gradom (Muggah, 2012); prevenciju prestupništva; jačanje demokratske kontrole i nadzora bezbednosnih strategija, smanjenje društvenih nejednakosti u pogledu prihoda domaćinstava i pristupa obrazovanju, zapošljavanju, zdravstvenoj zaštiti i stanovanju (Meško et al., 2013). U pojedinim zemljama formirani su i lokalni saveti za bezbednost koji funkcionišu kao konsultativna tela u oblasti kriminala i povezanim problemima bezbednosti. ${ }^{8}$ Većina ovih strategija i modela zasnovani su na pretpostavci da kombinovanje „tvrdih“ i „mekih“ mera bezbednosti, promocija lokalnih lidera i participacije građana, i periodično merenje efekata preventivnih programa mogu biti efikasan način redukcije kriminala u urbanom okruženju.

\section{PREPORUKE ZA KREIRANJE PROGRAMA PREVENCIJE KRIMINALA U GRADOVIMA}

Planiranje adekvatnih politika, programa i strategija prevencije kriminala u urbanim sredinama zahteva sagledavanje i analizu nekoliko značajnih faktora. Ukoliko urbani kriminal posmatramo u okviru šire perspektive bezbednosti u gradovima, holistički

\footnotetext{
${ }^{6}$ Jedan od najambicioznijih programa, zasnovanog na pretpostavkama koncepta Pametnog grada, razvijen je u Dablinu pod nazivom Dublinked. Ova platforma na nivou celog grada predstavlja servis otvorenih podataka u realnom vremenu koji se tiču različitih dimenzija života u gradu (od saobraćaja, životne sredine do antidruštvenih ponašanja). Zvanični podaci su dostupni građanima putem Dublin Dashboard, interaktivne mape, grafikona i aplikacija, na raznim lokacijama u gradu. Za pregled savremenih informaciono-komunikacionih alata koje građani mogu koristiti kako bi unapredili sopstvenu bezbednost u gradu pogledati Paraušić, 2018.

7 Projekat policije u zajednice, primenjen sa varijabilnim uspehom i u našoj zemlji, zasnovan je na saradnji policije i građana. Policija i zajednica rade zajedno kako bi identifikovali probleme, postavili prioritete i pronašli rešenja za bezbednosne pretnje poput kriminala, zloupotrebe droga, straha od kriminala, socijalnih problema, zagađenja životne sredine i drugih vidova antidruštvenog ponašanja u radnom i životnom okruženju (Meško, Lobnikar, 2005).

8 Meško i Lobnikar (2005) navode kao značajne prednosti formiranja ovakvih savetodavnih tela: decentralizaciju formalne socijalne kontrole; intenzivniju saradnju među građanima i ključnim akterima u oblasti lokalne bezbednosti; negovanje mentaliteta „zajednice koja brine“. Međutim, šire zasnivanje nadležnosti loklanih saveta bezbednosti naišlo je na brojne prepreke koje se obično tiču neregulisanih uloga, različitog razumevanja lokalnih problema bezbednosti, međusobnog nerazumevanja uključenih aktera, nezainteresovanosti građana i sl. (Meško, Lobnikar, 2005: 364).
} 
pristup preventivnim programima, podrazumeva analizu vrednosti koje kriminal kao pretnja ugrožava, kao i provajdera, odnosno subjekta koji preduzimaju odgovarajuće bezbednosne mere kako bi ovu negativnu pojavu redukovali ili sprečili. Pored uzročnika kriminala u urbanim sredinama i njegovih posledica, potrebno je proučiti specifične uslove koji karakterišu pojedinačne urbane sredine ili delove grada, ali i konkretne trendove kriminaliteta, kao i subjektivni doživljaj ljudi koji naseljavaju određeni prostor (ispitivanja straha od kriminala). Sveobuhvatna analiza trebalo bi da ukaže kako na adekvatne pravce delovanja, tako i na aktere u urbanom okruženju koji bi trebalo da se uključe u aktivnosti na planu prevencije urbanog kriminala.

Uzroci kriminala u pojedinim gradovima mogu biti vrlo različiti, kompleksni, ali i međuzavisni, tako da bi početni korak u kreiranju adekvatnih programa prevencije svakako trebalo da bude analiza stanja sredine u kojoj treba implementirati konkretan program. Iako se među najčěče navođenim faktorima rizika nastanka urbanog kriminala navode urbanizacija, gustina naseljenosti, siromaštvo, nejednakost i velika populacija mladih (Paraušić, 2019b), prediktori kriminala u gradovima su brojni, te je temeljno sagledavanje specifičnosti pojedinačnih urbanih sredina od vitalnog značaja kako bi se aktivnosti preventivnih programa usmerile na identifikovane uzročnike zločina. Neophodno je detaljno analizirati socioekonomsku i političku situaciju, kulturološke uslove, obrasce urbanizacije, kao i namenu konkretnog prostora. U odnosu na pomenute faktore čak se i delovi jednog grada mogu značajno razlikovati, te bi bilo koirsno planirati specijalne programe fokusirane na deprivirane društvene grupe, naročito one čiji pripadnici tradicionalno pribegavaju nasilju (nezbrinuta deca na ulici, mladi bez posla, zavisnici od narkotika). Programi reintegracije dece beskućnika koje sprovode nevladine organizacije, ili kao što je slučaj u Meksiku, kroz partnerstvo UNICEF-a i gradskih vlasti, pokazuju da ove inicijative mogu imati značajne efekte na redukciju krimianala (Vanderschueren, 1996: 107).

Osim evidentnih i najvidljivijih efekata kriminala, u vidu smrti, povrede ili individualne štete, kriminal u gradovima ima brojne i višeslojne posledice koje se reflektuju na različite dimenzije gradskog života. ${ }^{9}$ Urbani kriminal može imati vrlo negativne efekte na društveni kapital i koheziju, jer utiče destimulativno na strane i domaće investicije, stigmatizaciju susedstva, eroziju društvenih veza i sl. (Morenoff et al., 2001; Mcllwaine, Moser, 2001; Vial et al., 2010). Posledice mogu imati i šire razmere, kada urbani kriminal dovodi do socioprostorne segregacije građana, udaljavajući društvene grupe jedne od drugih i menjajući izgled urbanog područja (United Nations Centre for Human Settlements, 1996; Brennan, 1999; UN Habitat, 2007). Imajući u vidu ove heterogene i ozbiljne posledice, adekvatni programi prevencije urbanog kriminala ne bi trebalo da budu kreirani samo na osnovu prepoznatih uzroka ovog fenomena, već usmereni na različite posledice koji krivična dela izazivaju u specifičnim urbanim sredinama.

${ }_{9}$ Za detaljni prikaz posledica nasilja na urbanu bezbednost pogledati Muggah, 2012. 
Uočljivo je da se programi prevencije kriminala u gradovima, predstavljeni u prethodnom poglavlju, prvenstveno vezuju za urbane prostore SAD i Zapadne Evrope, te su iskustva u primeni ovih pristupa evaluirana u odnosu na urbani prostor ograničenog broja zemalja. Savremeni gradovi veoma se razlikuju po pitanju prevalencije određenih bezbednosnih problema, što je svakako posledica različitih obrazaca urbanizacije i razvoja grada, socio-ekonomskih uslova, strukture stanovništva, funkcije i strukture grada i sličnih pokazatelja. Opravdano se može očekivati da će programi prevencije zasnovani na uređenju okoline imati drugačije rezultate $\mathrm{u}$ gradovima skrominijih ekonomskih i institucionalnih kapaciteta. Značajne razlike $\mathrm{u}$ trendovima kriminaliteta $\mathrm{u}$ različitim delovima grada upućuje na zaključak da planiranje i sprovođenje programa prevencije moraju biti fleskibilni i osetljivi na društveni kontekst.

Treba imati u vidu i da na trenutne pokazatelje stanja kriminaliteta u nekom gradu utiče stopa prijavljivanja zločina, nedostatak poverenja u institucije, neizgrađeni ili nedovoljni kapaciteta, kao i generalna klima u pogledu nasilja i zastrašivanja. Osim toga, percepcija $\mathrm{i}$ iskustvo u zajednici, pogotovo žrtvava nasilnih zločina ili marginalizovanih grupa mogu ostati nevidlji, što je nekada ključno prilikom razumevanja i prepoznavanja izazova urbane bezbednosti (UNODC, 2016: 16). Adekvatno razumevanje svih izazova i pretnji sa kojima se suočvaju urbane zajednice zahteva postojanje adekvatnih tehnika i alata za prikupljanje podataka, na kojima bi se zasnivale konkretne politike, čiji bi rezultati mogli da se evaluiraju i koji bi bili dostupni zajednici.

Osim analize objektivnih pokazatelja nebezbednosti u gradu (ili delu grad ili susedstvu), neophodno je proučiti i subjektivnu dimenziju bezbednosti, tj. doživljaje stanovnika o bezbednosnim problemima. Ovde su svakako od velike koristi različita ispitivanja straha od kriminala u gradovima, ali i uzroka i pokretača osećaja nebezbednosti. Strah od kriminala obično je povezan sa tri dimenzije: afektivnom (emocionalna dimenzija), kognitivnom (procena rizika od viktimizacije) i bihejvioralnom (Rountree, Land, 1996; Gabriel, Greve, 2003; Beaulieu et al., 2007; Ferguson, Mindel, 2007). Stoga bi strategije prevencije urbanog kriminala trebalo da uvaže saznanja i zaključke do kojih se došlo sprovođenjem mnogobrojnih studija straha od kriminala, prilagođenih specifičnostima gradskog područja gde bi ih trebalo primeniti.

Prevencija kriminala više ne može podrazumevati uključivanje pojedinačnih subjekata formalne socijalne kontrole, imajući u vidu kompleksnost i različitost savremenih gradova. Adekvatno planiranje bilo kakve inicijative neminovno zahteva participaciju brojnih aktera: od policije i gradskih vlasti, preko eksperata (urbanih planera, arhitekata, naučnika), privatnih bezbednosnih snaga, kao i građana koji neposredno koriste prostor u kom treba sprovesti planiranu intervenciju. Ovo je naročito izraženo u inicijativama koje su orijentisane na zajednice, odnosno pojedince, koje zahtevaju da participacija građana bude osnovni sadržaj preventivnih programa usmerenih ka redukciji uličnog kriminala i straha od nasilja. Često se ističe kako bi zajedničkim radom građana i drugih relevantnih aktera u urbanim sredinama, gradovi trebalo da postanu održivi, kohezivni (promovisati inkluzivnost, različitost, bolje uslove stanovanja, društvenu solidarnost) i zasnovani 
na znanju, kako bi se preveniralno urbano nasilje, antisocijalno ponašanje i nesigurnost (Congress of Local and Regional Authorities, 2008). Problemi vezani za kriminal u urbanim sredinama mogu se efikasno tretirati kroz intervencije u okviru socijalnih i ekonomskih politika koje zahtevaju partnerstvo gradskih vlasti i građana (Edwards, Hughes, Lord, 2013: 263).

Osim specifičnih faktora na koje je moguće usmeriti analizu prilikom planiranja programa prevencije, moguće je izdvojiti i neke opšte preporuke koje mogu unaprediti pružanje bezbednosti u gradu, a čiji bi prevencija kriminala svakao trebalo da bude sastavni deo. Kao ilustraciju, predstavićemo sažeto preduslove za razvoj efektivnih strategija unapređenja urbane bezbednosti prema Programu bezbednih gradova (Safer Cities Programme) koji je razvio UN-Habitat. Prvo, mora postojati adekvatan institucionalni okvir i resursi za rešavanje bezbednosnih problema. Drugo, bezbednost urbanih zajednica ne sme biti isključiva odgovornost policije ili organizacija specijalizovanih za rešavanje konkretnih problema, već šire mreže aktera. Treće, potrebno je razviti mehanizme koji omogućavaju učešće što šireg kruga građana, kroz aktivnosti kao što su konsultacije, edukacije i inicijative na nivou susedstva. Četvrto, neophodno je podsticati mere transparentnosti, kao što su inicijative protiv korpucije, redovno izveštavanje o napretku inicijativa, ali sposobnost da se odgovor na bezbednosne probleme menja u skladu sa promenljivim okolonostima i potrebama (Whitzman, 2008: 127).

\section{ZAKLJUČNE NAPOMENE}

Pregled nekih od postojećih programa prevencije kriminala u urbanom okruženju ukazuje na nekoliko važnih zaključaka. Prvo, očigledan je otklon od pristupa prema kome je prevencija kriminala isključivo zadatak organa formalne socijalne kontrole, policije i pravosuđa pre svega, te se u tom smislu potencira ideja o urbanom kriminalu kao fenomenu koji zahteva sveobuhvatan odgovor. Stoga ne iznenađuje da se u programima gradskih vlasti često ističe prevencija kriminala kao jedan od ciljeva ostvarenja bezbednosti zajednice. Drugo, umesto ad hoc, jednokratnih rešenja, potrebno je kreirati dugoročna rešenja, koja su zasnovana na naučnim saznanjima i koja kombinuju više različitih pristupa. Treće, partnerstvo različitih aktera na nivou grada jedna je od ključnih pretpostavki sprovođenja programa prevencije. Dalje, neophodno je dobro analizirati i uvažiti lokalni kontekst pre bilo kakvog planiranja preventivnih aktivnosti, umesto direktnog sprovođenja rešenja koje je dalo uspeha u drugačijem urbanom okruženju. Pravilno kreiranje programa prevencije, onih koji ce biti dovoljno sveobuhvatni, ali istovremeno senzitivni na specifične potrebe zasebnih delova grada ili susedstva, od presudnog je značaja za unapređenje stanja urbane bezbednosti i smanjenje straha od kriminala. Na kraju, potrebno je ustanoviti mehanizme evaluacije programa i redovnog izveštavanja javnosti o sprovedenim aktivnostima.

Postojeća iskustva u implementaciji programa prevencije upućuju na to da su gradskim vlastima, zajednici, policiji, urbanistima i građanima dostupna brojna rešenja koja dokazano smanjuju prilike i mogućnosti da se kriminal dogodi. 


\author{
Zbornik IKSI, 2-3/202O - A. Paraušić \\ „Prevencija kriminala kao pristup unapređenju urbane bezbednosti”, (str. 93-107)
}

Smanjenje stopa kriminaliteta i straha građana od kriminala unapređuju ukupan nivo urbane bezbednosti i kvalitet života $u$ gradu. Iskustva u programima ovakvog tipa pokazala su da zajedničke aktivnosti svih zainteresovanih strana predstavljaju osnovu za buduća partnerstva za rešavanje bezbednosnih problema i povećanje kontrole susedstva od strane građana. Partnerski odnos, odnosno potreba da $\mathrm{u}$ planiranju i primeni preventivnih programa učestvuju osobe i institucije sa područja na kom će se intervencija implementirati, predstavljaju jedan od ključnih faktora uspešne prevencije.

Svaki vid prevencije, manje „košta“ zajednicu, doprinosi unapređenju kvaliteta života u gradu, doprinosi koheziji i otovrenosti urbanih sredina, i u krajnjem podiže sveukupni nivo urbane bezbednosti. Bez obzira na dugu tradiciju izučavanja i impresivan akademski opus o ovom fenomenu, imajući u vidu prevalenciju, posledice i značaj koji ima u savremenim gradovima, urbani kriminal zaslužuje neprekidnu pažnju, kako u akademskim krugovima, tako i među donosiocima odluka. Politike i programi zasnovani na naučnim saznanjima omogućavaju sveobuhvatan odgovor na problem urbanog kriminala, identifikaciju izazova dosadašnjih pristupa, kao i unapređenje kapaciteta i sposobnosti formalnih i neformalnih provajdera urbane bezbednosti uključenih u proces prevencije kriminala u gradovima.

\title{
LITERATURA
}

(1) Armitage, R. (2004) Secured by Design: An Investigation of its History, Development and Future Role in Crime Reduction. Ph.D. Thesis. Huddersfield: University of Huddersfield.

(2) Beaulieu, M., Dube, M., Bergeron, C. \& Cousineau, M. (2007). Are elderly men worried about crime? Journal of Aging Studies 21(4), pp. 336-346. https://doi.org/10.1016/j.jaging.2007.05.001

(3) Brennan, E. M. (1999) Population, urbanization, environment, and security: a summary of the issues. Environmental Change and Security Project Report (Issue 5). Washington, D.C: The Woodrow Wilson Center.

(4) Chan, E. \& Lee, G. K. (2008) Critical factors for improving social sustainability of urban renewal projects. Social Indicators Research, 85(2), pp. 243-256. https://doi.org/10.1007/s11205-007-9089-3

(5) City of Virginia Beach. (2000) Crime Prevention through Environmental Design: General Guidelines for Designing Safer Communities. City of Virginia Beach.

(6) Clarke, R. V. (1982) Crime Prevention through Enviormental Managment and Design. In: Gunn, J. C., Farrington, D. P., Abnormal Offenders, Delinquency and the Criminal Justice System. London and New York: Wiley.

(7) Congress of Local and Regional Authorities. (2008) European Urban Charter IIManifesto for a New Urbanity. Strasbourg: Congress of Local and Regional Authorities.

(8) Cozens, P., Hillier, D. \& Prescott, G. (2001). Crime and the design of residential property-exploring the theoretical background-Part 1. Property management, 19(2), pp. 136-164. https://doi.org/10.1108/02637470110388235

(9) Cozens, P.M., Saville, G., \& Hiller, D. (2005) Crime Prevention throuh Environmental Design (CPTED): a Review and Moder Bibliography. Property Manager, 23(5), pp. 328-356. 


\section{Zbornik IKSI, 2-3/202O - A. Paraušić \\ „Prevencija kriminala kao pristup unapređenju urbane bezbednosti”, (str. 93-107)}

(10) CSIR Building and Constructions Technology (2001) Crime Prevention through Environmental Design. Pretoria: CSIR.

(11) Danilović-Hristić, N. (2014) Urbana bezbednost i prevencija uličnog kriminala kao preduslovi za razvoj zdrave zajednice. Acta historiae medicinae, stomatologiae, pharmaciae, medicinae veterinariae, 33(1), str. 16-30.

(12) Đurić, S. (2013) Strah od kriminala, rodne razlike u percepciji rizika. Sociološki pregled, 47(4), str. 537-554. https://doi.org/10.5937/socpreg1304537D.

(13) Đurić, S., \& Paraušić, A. (2017). Urbano planiranje kao okvir za redukovanje straha od kriminala. U: S. Stanarević i A. Đukić (Ur.) Urbana bezbednosti i urbani razvoj (Knjiga sažetaka). Prva naučna konferencija „Urbana bezbednost i urbani razvoj“, 21. jun 2017. Beograd. Beograd: Univerzitet u Beogradu - Fakultet bezbednosti, str. (122-128).

(14) Edwards, A., Hughes, G., \& Lord, N. (2013) Urban security in Europe: Translating a concept in public criminology. European Journal of Criminology, 1O(3), pp. 260283. https://doi.org/10.1177/1477370813483386

(15) Ferguson, K. M. \& Mindel, C. H. (2007) Modeling fear of crime in Dallas neighborhoods: A test of social capital theory. Crime \& Delinquency, 53(2), pp. 322349. https://doi.org/10.1177/o011128705285039

(16) Gabriel, U., \& Greve, W. (2003) The psychology of fear of crime. Conceptual and methodological perspectives. British Journal of Criminology, 43(3), 600-614. https://doi.org/10.1093/bjc/43.3.600

(17) Jacobs, J. (1961) The death and life of great American cities. New York: Random House.

(18) Jeffery, R. C. (1971) Crime prevention through environmental design. Beverly Hills, CA: Sage.

(19) Kitchen, R. \& Dodge, M. (2017) The (In)Security of Smart Cities: Vulnerabilities, Risks, Mitigation and Prevention. Journal of Urban Tecnology, 26(2), 47-65. https://doi.org/10.1080/10630732.2017.1408002

(20) Lorenc, T., Clayton, S., Neary, D., Whitehead, M., Petticrew, M., Thomson, H., ... \& Renton, A. (2012). Crime, fear of crime, environment, and mental health and wellbeing: mapping review of theories and causal pathways. Health \& place, 18(4), pp. 757-765. https://doi.org/10.1016/j.healthplace.2012.04.001

(21) McIlwaine, C., \& Moser, C. O. (2001) Violence and social capital in urban poor communities: perspectives from Colombia and Guatemala. Journal of International Development, 13(7), pp. 965-984 https://doi.org/10.1002/jid.815

(22) Meško, G., \& Lobnikar, B. (2005) The contribution of local safety councils to local responsibility in crime prevention and provision of safety. Policing: An international journal of police strategies \& management, 28(2), pp. 353-373. https://doi.org/10.1108/13639510510597951

(23) Meško, G., Tominc, B., \& Sotlar, A. (2013) Urban security management in the capitals of the former Yugoslav republics. European Journal of Criminology, 10(3), pp. 284-296. https://doi.org/10.1177/1477370812473537

(24) Morenoff, J. D., Sampson, R. J., \& Raudenbush, S. W. (2001) Neighborhood inequality, collective efficacy, and the spatial dynamics of urban violence. Criminology, 39(3), pp. 517-558. https://doi.org/10.1111/j.17459125.2001.tboo932.x

(25) Muggah, R. (2012) Researching the urban dilemma: Urbanization, poverty and violence. Ottawa: International Development Research Centre.

(26) National Crime Prevention Council (2003) Crime Prevention throug Environmental Design Guidebook. Washington, DC.: NCPC.

(27) Newman, O. (1972) Defensible space: Crime prevention through urban planning. New York: Macmillan 


\author{
Zbornik IKSI, 2-3/202O - A. Paraušić \\ „Prevencija kriminala kao pristup unapređenju urbane bezbednosti”, (str. 93-107)
}

(28) Paraušić, A. (2018). Smart city ICT Solutions for Enhancing Human Security. In: S. Stanarević, G.J. Mandić \& Lj. Katić (Eds.) The Proceedings of Human Security and New Technologies. $4^{\text {th }}$ International Academic Conference on Human Security, 2-3 November 2018, Belgrade. Belgrade: Faculty of Security Studies, Human Security Research Center (pp. 241-247).

(29) Paraušić, A. (2019a) Bezbednost u gradovima van granica nacionalnog i lokalnog Politike urbane bezbednosti evropskih organizacija. Revija za kriminologiju $i$ krivično pravo, 57(2), str. 99-111.

(30) Paraušić, A. (2019b) Nasilnički kriminal kao bezbednosni problem u gradovima. Zbornik Instituta za kriminološka i sociološka istraživanja, 38(3), str. 119-135

(31) Pavićević, O. (2019) Zelene urbane površine i kriminalitet. Zbornik Instituta za kriminološka i sociološka istraživanja, 38(1), str. 51-63.

(32) Recasens, A., Cardoso, C., Castro, J., \& Nobili, G. G. (2013) Urban security in southern Europe. European Journal of Criminology, 10(3), pp. 368-382. https://doi.org/10.1177/1477370812473535

(33) Review of CEN 14383: The death and life of great European standards and manuals - Development and implementation of the CEN 14383 standards. 2014. COST Action TU1203 prezeto 23.04.2017 sa http://costtu1203.eu/wpcontent/uploads/2014/10/o3.-Review-of-CEN-14383-The-death-and-life-of-geatEuropean-standards-and-manuals.pdf

(34) Robinson, M. B. (2013). The theoretical development of "CPTED”: Twenty-five years of responses to C. Ray Jeffery. In: W. Laufer \& F. Adler (Eds.) (2013). The criminology of criminal law, 8. New Brunswick: Transaction Publisher, (pp. 427-462).

(35) Rountree, P. W. \& Land, K. C. (1996) Perceived risk versus fear of crime: Empirical evidence of conceptually distinct reactions in survey data. Social Forces, 74(4), pp. 1353-1376. https://doi.org/10.1093/sf/74.4.1353

(36) Sampson, R. J., \& Raudenbush, S. W. (2004). Seeing disorder: Neighborhood stigma and the social construction of "broken windows". Social psychology quarterly, 67(4), 319-342. https://doi.org/10.1177/019027250406700401

(37) Shaw, C. R., \& McKay, H. D. (1942). Juvenile delinquency and urban areas. Chicago: University of Chicago Press.

(38) Swatt, M. L., Varano, S. P., Uchida, C. D. \& Solomon, S. E. (2013) Fear of crime, incivilities, and collective efficacy in four Miami neighborhoods. Journal of Criminal Justice, 41(1), pp. 1-11. https://doi.org/10.1016/j.jcrimjus.2012.09.004

(39) Tulumello, S. (2017). The multiscalar nature of urban security and public safety. Urban Affairs Review, 54(6), pp. 1134-1169. ttps://doi.org/10.1177/1078087417699532

(40) United Nations Centre for Human Settlements (UNCHS) (1996) An Urbanizing World: Global Report on Human Settlements. Oxford: Oxford University Press

(41) Un-Habitat. (2007) Enhancing urban safety and security: Global report on human settlements 2007. London: Routledge.

(42) UNODC (2016) Governing Safer Cities: Strategies for a Globalised World. Vienna: UNODC.

(43) Vanderschueren, F. (1996) From violence to justice and security in cities. Environment and Urbanization, 8(1), pp. 93-112. https://doi.org/10.1177/095624789600800119

(44) Vial, E. A., Junges, J. R., Olinto, M. T., Machado, P. S., \& Pattussi, M. P. (2010) Urban violence and social capital in a southern Brazilian city: a quantitative and qualitative study. Revista panamericana de salud publica=Pan American journal of public health, 28(4), pp. 289-297. https://doi.org/10.1590/s102049892010001000008 


\author{
Zbormik IKSI, 2-3/2020 - A. Paraušić \\ „Prevencija kriminala kao pristup unapređenju urbane bezbednosti”, (str. 93-107)
}

(45) Waller, I. (2006) Effective Measures for the Prevention of Crime Associated with Urbanization. In: 129th International senior seminar visiting experts' papers. Tokyo: UNAFEI, (pp. 75-88).

(46) Welsh, B. C. \& Farrington, D. P. (2008a) Effects of improved street lighting on crime. Campbell Systematic Reviews, 4(1), pp. 1-51. https://doi.org/10.4073/csr.2008.13

(47) Welsh, B. C. \& Farrington, D. P. (2008b) Effects of closed circuit television surveillance on crime. Campbell Systematic Reviews, 4(1), pp. 1-73. https://doi.org/10.4073/csr.2008.17

(48) Whitzman, C. (2008) The handbook of community safety, gender and violence prevention: practical planning tools. London: Earthscan.

(49) Wilson, J. Q., \& Kelling, G. L. (1982) Broken windows. Atlantic monthly, 249(3), pp. 29-38.

(50) Worrall, J. L. (2006) The discriminant validity of perceptual incivility measures. Justice Quarterly 23(3), pp. 360-383. https://doi.org/10.1080/07418820600869137

(51) Параушић, А. \& Липовац, М. (2019) Карактеристике претњи урбаној безбедности. Политичка ревија, 6о(2), стр. 255-277. https://doi.org/10.22182/pr.6022019.12

\title{
CRIME PREVENTION AS AN APPROACH TO URBAN SECURITY ENHANCEMENT
}

Urban crime is one of the traditional themes in criminology, and the contemporary research on this phenomenon is connected with the concept of urban security. From this perspective, urban crime, could be seen as a security threat, and the crime prevention as one of the models, policies or security measures that security providers implement to achieve security in the city. This paper aims at addressing the main features of crime prevention in the cities, which is in the function of improving urban security. In the first part of the paper, some theoretical assumptions on which the modern study of urban crime prevention is based are reviewed. Then, certain models, strategies and policies for crime prevention in the cities based on the rich research practice in this area are presented. Finally, some recommendations are given for adequate planning of crime prevention programs that could contribute to the overall enhancement of urban security.

KEY WORDS: urban crime / crime prevention / urban security 
